\title{
A framework for assessing the risk of resistance for antimalarials in development
}

\author{
Xavier C Ding ${ }^{*}$, David Ubben, Timothy NC Wells \\ From Challenges in malaria research \\ Basel, Switzerland. 10-12 October 2012
}

Because they kill sensitive organisms, anti-infective agents are bound to exert an evolutionary pressure toward the emergence and spread of resistance mechanisms. Common to all infectious diseases, this vicious circle is especially acute for malaria. P. falciparum resistance to chloroquine and sulfadoxine-pyrimethamine became so widespread that these former first-line treatments had to be abandoned [1]. Today, in certain areas, $P$. falciparum parasites appear to gradually lose their sensitivity to artemisinin derivatives, on which are based the current therapies for both uncomplicated and severe $P$. falciparum malaria [2,3]. New classes of antimalarial medicine are urgently needed to stay ahead in the resistance arms race. These should be designed not only to overcome existing resistance mechanisms, but also to prevent the emergence of de novo resistance for as along as possible.

Cell-based screening methods have led to a renaissance of new classes of anti-malarial compounds [4], offering us the potential to select and modify molecules based on their resistance potential. In order to quantitatively assess this potential in P. falciparum, we developed a standardized ex vivo methodology that can be applied during the early phases of the drug development process. Crossresistance is evaluated through a panel of specific multidrug resistant strains designed to cover all genetically validated resistance mechanisms known to occur in the field. Second, the genetic ability of $P$. falciparum to evolve a genetically encoded resistance mechanism is quantified by measuring the minimal inoculum for resistance (MIR), that is the minimal number of parasite from which a resistant mutant is likely to be selected ex vivo by a constant low level of drug pressure. Further, the generation of resistant parasites possibly facilitates the understanding of the compound mode-of-action and permits the identification of resistance markers, which are

Medicines for Malaria Venture, 20 rtede Pré Bois, CH 1215 Geneva, Switzerland essential for resistance monitoring during the clinical development and post-marketing surveillance phases.

Altogether, these and other parameters, such as resistant parasite fitness and gametocyte production, define a comprehensive profile, which allows the identification of overt risks and the active prioritization of the most robust antimalarials in a cost-effective manner.

Published: 15 October 2012

\section{References}

1. World Health Organization: Global report on antimalarial drug efficacy and drug resistance: 2000-2010. Geneva: WHO; 2010, 121.

2. Dondorp AM, Yeung S, White L, Nguon C, Day NPJ, Socheat D, Seidlein von L: Artemisinin resistance: current status and scenarios for containment. Nat Rev Micro 2010, 8:272-280.

3. Phyo AP, Nkhoma S, Stepniewska K, Ashley EA, Nair S, McGready R, Ler Moo C, Al-Saai S, Dondorp AM, Lwin KM, Singhasivanon P, Day NP, White NJ, Anderson TJ, Nosten F: Emergence of artemisinin-resistant malaria on the western border of Thailand: a longitudinal study. Lancet 2012.

4. Wells TNC: Is the Tide Turning for New Malaria Medicines? Science 2010, 329:1153-1154.

doi:10.1186/1475-2875-11-S1-P23

Cite this article as: Ding et al:: A framework for assessing the risk of resistance for antimalarials in development. Malaria Journal 2012 11(Suppl 1):P23.

Submit your next manuscript to BioMed Central and take full advantage of:

- Convenient online submission

- Thorough peer review

- No space constraints or color figure charges

- Immediate publication on acceptance

- Inclusion in PubMed, CAS, Scopus and Google Scholar

- Research which is freely available for redistribution
C 2012 Ding et al; licensee BioMed Central Ltd. This is an Open Access article distributed under the terms of the Creative Commons Attribution License (http://creativecommons.org/licenses/by/2.0), which permits unrestricted use, distribution, and reproduction in any medium, provided the original work is properly cited. 